Relations industrielles

Industrial Relations

\title{
Craypo, Charles, and Bruce Nissen, Grand Designs : The Impact of Corporate Strategies on Workers, Unions, and Communities
}

\section{Dale Belman}

Volume 49, numéro 3, 1994

URI : https://id.erudit.org/iderudit/050963ar

DOI : https://doi.org/10.7202/050963ar

Aller au sommaire du numéro

Éditeur(s)

Département des relations industrielles de l'Université Laval

ISSN

0034-379X (imprimé)

1703-8138 (numérique)

Découvrir la revue

Citer ce compte rendu

Belman, D. (1994). Compte rendu de [Craypo, Charles, and Bruce Nissen, Grand Designs : The Impact of Corporate Strategies on Workers, Unions, and Communities]. Relations industrielles / Industrial Relations, 49(3), 606-608. https://doi.org/10.7202/050963ar

Tous droits réservés @ Département des relations industrielles de l'Université Laval, 1994
Ce document est protégé par la loi sur le droit d'auteur. L'utilisation des services d'Érudit (y compris la reproduction) est assujettie à sa politique d'utilisation que vous pouvez consulter en ligne.

https://apropos.erudit.org/fr/usagers/politique-dutilisation/ 
Recently, a number of country-by-country comparisons have been published, in particular on Europe, like the Baglioni/Crouch and the Ferner/Hyman volumes. It is tempting to make a comparison, despite the fact that this book only covers five European countries, in addition to four other nations. I would say that this book is more of a unity than any of the other two, but that the comparative chapters in the other volumes offer more of a real comparison. While the Baglioni/Crouch volume is too diverse to serve as an introduction, the Ferner/Hyman survey is a more analytical one, up to the point of taking for granted a lot of knowledge about some of the countries covered there. I agree with Streeck's conclusion, cited on the (beautiful) cover, that this is 'a good first introduction to comparative industrial relations'. It may not be a better introduction than the other volumes, but it definitely is the best first introduction.

Hans Slomp

Cornell University

Grand Designs: The Impact of Corporate Strategies on Workers, Unions, and Communities, by Charles Craypo and Bruce Nissen, Ithaca, NY, ILR Press, 1993, 285 p., ISBN 0-87546-309-6 (acid-free paper) and ISBN 0-87546-310-X (pbk).

Publication of The Transformation of U.S. Industrial Relations focused scholars on the role of corporate strategy in guiding relations between managers and workers. Grand Designs furthers our understanding of corporate approaches through detailed analyses on how they affect workers and communities and how those affected have responded to corporation actions. Through nine case studies, the book moves from situations in which companies imposed their strategies on workers without effective opposition to those in which labor-community coalitions were able to compel firms to negotiate through use of national laws and political pressure. The employee-community perspective and the detail of the studies provide useful balance to a literature which has tended toward abstraction and a management oriented outlook.

Several themes run through these studies of plant closing and union decertification in the heavily industrialized Midwest of the United States. First, it appears that corporate strategies are less the inevitable consequence of changing markets than the outcome of how firms have chosen to respond to these pressures. The low wage non-union strategy is only one of several possible approaches. Second, labor concessions alone are unlikely to change corporate managements approach to the problem. Similarly, traditional business oriented community development strategies of providing subsidies and tax relief to companies are also unlikely to alter corporate strategies. Finally, development of labor-community coalitions and the judicious use of political and legal leverage can provide workers and communities a means of opposing the strategies which lead to labor and community decline.

The first and second themes are apparent in most of the case studies. Charles Jeszek's study of the decline of tire manufacturing in Akron is particularly illustrative. Akron's decline was apparently due to of the failure of the American firms to make timely investments in radial tire technology and a decision to build new plants 
elsewhere. Although the Akron locals of the United Rubber Workers responses to company demands varied from giving the concessions to categorical resistance, the outcome was the same in each instance. The firms used concessions in the Akron plants to obtain funds to build new plants with more viable products in other localities and as bargaining chips to whipsaw concessions from the new plants. In retrospect, there was little workers in Akron could do to save their plants and jobs because they had no effective levers to influence firm's 'strategic' decisions.

The shortcomings of business oriented state and local government development approaches are also apparent from several studies. Governments have advanced funds and forgone tax revenues in the ongoing competition to attract and retain plants which provide jobs. Despite understandings and agreements that funds and concessions would be used to keep jobs in a local and would not be used to finance relocations, firms such as Playskool, Diamond Tool, and Amhoist accepted subsidies and restrictions while planning to relocate the jobs involved. The only penalty they risked was having to return money. The study of the closing of the Blau-Know foundry illustrates the limitations of reason without power. A detailed report by a major consulting firm and effort by workers and local officials did not convince the parent company to restructure the operation to make it more profitable. Instead, the company sold the plant to a firm which ran the plant into the ground extracting short-term profits. As in union negotiations, reason alone does not suffice.

The most interesting cases are the studies of lowa Beef Processors (IBP) and of several projects undertaken by the Calumet Project for Industrial Jobs (CPIJ), in which labor community coalitions successfully resisted corporate strategies. In the IBP case, the corporate practice of using low wage, poorly trained workers and running very fast slaughter lines laid the groundwork for the coalition between the United Food and Commercial Workers Union and the citizens in the affected communities. High injury rates led IBP to falsify OSHA logs, while the communities in which the IBP plants were located found themselves facing unprecedented demands on their resources from the large low wage labor forces attracted to the plants. The coalition between the community and workers in the Sioux City plant, and the threat of fines and Congressional contempt citations against important company officials resulted in a successful strike in the mid-1980's. This strategy has been replicated in at least one other IBP location.

The study of the CPIJ by Bruce Nissen illustrates ways of preventing plant closing and promoting the passage of laws which limit unbalanced tax abatements to firms through development of labor-community coalitions. The creation of a strong coalition between local unions and community organizations, judicious use of media, active intervention by public officials, and questions concerning the legitimacy of the firm position were all important to the successes in the Calumet area. Another lesson from this study is the level of commitment and strategic and tactical sophistication required to achieve such victories.

Though the studies are exceeding interesting, the quality of the essays is uneven. Several writers did an outstanding jobs of integrating the factual material with information about market structure and corporate strategy. Others recount little more than the facts of a particular case. There are also rhetorical excesses and several essays, which appear to have been written in the late 1980 's, would have benefitted from updating. 
It would be useful to know the eventual outcome of the employee suit against Navistar and whether Hammond's restrictions on tax-abatements has served the city well.

Despite these shortcomings, this modest volume will be useful both to show how corporate strategies look from the shop floor and how, through a combination of perseverance, excellent strategy, and good fortune, some of those on the shop floor have successfully challenged the dominance of business power in our society.

Dale BeLMan

Economic Policy Institute

Washington, DC

A Primer on American Labor Law, by W.B. Gould IV, $3^{e}$ édition, Cambridge, MrT Press, 1993, 326 p., ISBN 0-262-07149-5 (reliure toile), ISBN 0-262-57099-8 (reliure cartonnée).

Il convient de s'arrêter à cette troisième édition de l'ouvrage originaire, déjà recensé [voir (1983) 38 Relations industrielles 180]. Il s'agit toujours, en effet, comme nous le constations alors, de l'une des rares véritables synthèses du droit du travail américain, au milieu d'une prolifération d'écrits à caractère technique. Or, le besoin de connaissance de ce droit de la première puissance économique mondiale ne peut que croître, en particulier au Canada, compte tenu de l'entrée en vigueur, en janvier dernier, de l'Accord nord-américain de coopération dans le domaine du travail, complément de l'ALENA, accord ayant notamment pour objectif d'assurer une « meilleure compréhension mutuelle des lois régissant le travail sur le territoire de chacune des parties ».

Le contenu général de cette troisième édition correspond substantiellement, sous réserve d'une certaine amplification, à celui du texte initial, dont il réitère d'ailleurs la structure. Axé primordialement sur le droit des rapports collectifs du travail, on y présente avec une heureuse insistance les antécédents historiques du régime actuel issu du New Deal, avant d'exposer les aspects prédominants de ce dernier: désignation du représentant collectif, les différentes pratiques déloyales en matière de représentation et de négociation collectives, l'appréhension juridique de celle-ci, y compris la licéité du recours aux différents moyens de pression, le régime de l'arbitrage de grief de convention collective, l'obligation de représentation égale du représentant collectif et l'intervention législative en matière de démocratie syndicale. Les deux derniers chapitres sont toujours consacrés au particularisme du secteur public, de même qu'à la législation normative et d'intérêt public.

Toute cette matière fait naturellement l'objet d'une mise à jour. On y traite ainsi notamment de la jurisprudence récente du NLRB (affaire Électromation Inc.) relative à la légalité de comités d'entreprise (p. 47), de la tentative avortée d'introduire des dispositions anti-briseurs de grève dans la loi fédérale, de l'entreprise de démocratisation des Teamsters en 1991 (p. 168)... Ceci dit, les innovations les plus marquantes ont trait à la législation directement protectrice de l'ensemble des salariés : obligation de préavis de fermeture de l'établissement en 1988 (p. 115), congé parental et de maladie de 1993 (p. 194), interdiction de discrimination fondée sur le handicap en 1992 (p. 200), multiplicité dans les lois de différents états des restrictions au licenciement ad nutum 